\title{
Localization of Type I Inositol 1,4,5-Triphosphate Receptor in the Outer Segments of Mammalian Cones
}

\author{
Tian-Li Wang, Peter Sterling, and Noga Vardi \\ Department of Neuroscience, University of Pennsylvania, Philadelphia, Pennsylvania 19104
}

\begin{abstract}
Calcium enters the outer segment of a vertebrate photoreceptor through a cGMP-gated channel and is extruded via a $\mathrm{Na} / \mathrm{Ca}$, $\mathrm{K}$ exchanger. We have identified another element in mammalian cones that might help to control cytoplasmic calcium. Reverse transcription-PCR performed on isolated photoreceptors identified $\mathrm{mRNA}$ for the $\mathrm{SII}^{-}$splice variant of the type I receptor for inositol 1,4,5-triphosphate $\left(\mathrm{IP}_{3}\right)$, and Western blots showed that the protein also is expressed in outer segments. Immunocytochemistry showed type $\mathrm{I} \mathrm{IP}_{3}$ receptor to be abundant in red-sensitive and green-sensitive cones of the trichromatic monkey retina, but it was negative or weakly expressed in blue-sensitive cones and rods. Similarly, the green-sensitive cones expressed the receptor in dichromatic retina (cat, rabbit,
\end{abstract}

and rat), but the blue-sensitive cones did not. Immunostain was localized to disk and plasma membranes on the cytoplasmic face. To restore sensitivity after a light flash, cytoplasmic cGMP must rise to its basal level, and this requires cytoplasmic calcium to fall. Cessation of calcium release via the $\mathrm{IP}_{3}$ receptor might accelerate this fall and thus explain why the cone recovers much faster than the rod. Furthermore, because its own activity of the $\mathrm{IP}_{3}$ receptor depends partly on cytoplasmic calcium, the receptor might control the set point of cytoplasmic calcium and thus affect cone sensitivity.

Key words: photoreceptor; $\mathrm{Ca}^{2+}$; $S$ cone; $M$ cone; L cone; phospholipase C; monkey
Sensitivity of vertebrate photoreceptors is regulated by cytoplasmic $\mathrm{Ca}^{2+}\left(\left[\mathrm{Ca}^{2+}\right]_{\mathrm{i}}\right)$ (Lamb and Torre, 1990; Koch, 1995; McNaughton, 1995; Koutalos and Yau, 1996) (for review, see Yau, 1994). $\mathrm{Ca}^{2+}$ enters the outer segment via cGMP-gated channels, is buffered by calcium binding proteins, and exits via the $\mathrm{Na} / \mathrm{Ca}$, K exchanger (Korenbrot, 1995) (for review, see Schnetkamp, 1995a). The outer segment contains an additional store of $\mathrm{Ca}^{2+}$ within membrane saccules (disks) that resemble smooth endoplasmic reticulum (Liebman, 1974; Fain and Schroder, 1985; Nicol et al., 1987; Schnetkamp and Bownds, 1987). Because the latter releases stored $\mathrm{Ca}^{2+}$ via an inositol 1,4,5-triphosphate $\left(\mathrm{IP}_{3}\right)$ receptor or a ryanodine receptor (Berridge, 1993; Mikoshiba et al., 1994), so might the disks bear such a receptor and provide an additional source of cytoplasmic $\mathrm{Ca}^{2+}$.

Indeed, a light flash to bovine outer segment membranes releases $\mathrm{IP}_{3}$ (Ghalayini and Anderson, 1984; Hayashi and Amakawa, 1985; Brown et al., 1987), and an $\mathrm{IP}_{3}$ receptor has been identified biochemically (Day et al., 1993). Although an antibody against purified brain $\mathrm{IP}_{3}$ receptor did not bind to outer segments (Peng et al., 1991), the $\mathrm{IP}_{3}$ receptor is encoded by at least four genes, each of which might be spliced into several isoforms (Danoff et al., 1991; Nakagawa et al., 1991; Lin, 1995; Nucifora et al., 1995). Therefore, a negative immunoreaction

\footnotetext{
Received Jan. 4, 1999; revised March 8, 1999; accepted March 16, 1999.

This work was supported by National Institutes of Health Grants EY11105-0 and EY08124. We thank Drs. Paul Liebman, Edward Pugh, Robert Smith, William Agnew, and Suresh K. Joseph for insightful discussions. We also thank Yi-Jun Shi and Tina Geueke for excellent technical assistance and John Demb and Madeleine Johnson for reading this manuscript. Antibodies are kind gifts from Drs. Suresh K. Joseph, William Agnew, Dan Wu, and Jeremy Nathans.

Correspondence should be addressed to Dr. Noga Vardi, Department of Neuroscience, University of Pennsylvania, 122B Anatomy/Chemistry Building, Philadelphia, PA 19104.

Dr. Wang's present address: Department of Pathology, Johns Hopkins University, School of Medicine, Baltimore, MD 21205.

Copyright (C) 1999 Society for Neuroscience $\quad 0270-6474 / 99 / 194221-08 \$ 05.00 / 0$
}

could result simply from a mismatch between isoform and antibody. Here we show by RT-PCR, Western blot, and immunocytochemistry that photoreceptor outer segments express the $\mathrm{SII}^{-}$

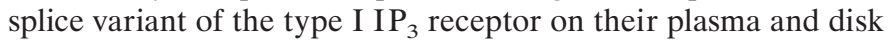
membranes. The receptor is more abundant in red- and greensensitive cones than in blue-sensitive cones and rods.

\section{MATERIALS AND METHODS}

Tissue sources

Eyes were enucleated under deep anesthesia from adult rat (Sprague Dawley), rabbit (Dutch-Belted), guinea pig (Dunkin Hartley), cat, and monkey (Macaca mulatta). All procedures complied with federal regulations and University of Pennsylvania policies.

\section{Dissociating photoreceptors}

Small pieces of rat retina were incubated in oxygenated Hank's medium (Life Technologies, Gaithersburg, MD) containing $14.4 \mathrm{U} / \mathrm{ml}$ papain, 0.1 $\mathrm{gm} / \mathrm{ml}$ cysteine, and $0.5 \mathrm{~mm}$ EDTA for $10 \mathrm{~min}$ at $28^{\circ} \mathrm{C}$. After the retina was rinsed with papain-free Hank's medium containing $0.5 \%$ bovine serum albumin, the retina was triturated gently with a wide-bore Pasteur pipette. An aliquot of dissociated cell suspension was diluted with Hank's medium and dropped on a cover glass coated with concanavalin A (Sasaki and Kaneko, 1996). After $30 \mathrm{~min}$, most cells attached to the coated cover glass, which then was washed with Hank's medium at least five times to remove loose cells. Isolated photoreceptors were identified by their characteristic morphology (see Fig. $1 C$ ) and sucked into a patch pipette.

\section{Reverse transcription-PCR (RT-PCR)}

Total RNA from both whole retina and photoreceptors was isolated by acid guanidium and phenol-chloroform extraction (Chomzynski and Sacchi, 1987). The reverse transcription (RT) reaction was performed at $42^{\circ} \mathrm{C}$ for 50 min with $1-5 \mu \mathrm{g}$ of total RNA in a $20 \mu \mathrm{l}$ buffer containing (in mM) 50 Tris- $\mathrm{HCl}, \mathrm{pH} 7.4,60 \mathrm{KCl}, 10 \mathrm{MgCl}_{2}, 1 \mathrm{DTT}$, and 0.5 of each dNTP plus $1 \mathrm{U} / \mathrm{ml}$ RNase inhibitor, 500 pmol random hexamer or 100 pmol of oligo dT, and $200 \mathrm{U}$ of Super II M-MLV reverse transcriptase (Life Technologies). PCR reaction was performed in a buffer containing (in mM) 10 Tris, $\mathrm{pH} 8.3,50 \mathrm{KCl}, 2.5 \mathrm{MgCl}_{2}$, and $0.4 \mathrm{dNTP}$ plus $0.2 \mu \mathrm{M}$ $5^{\prime}$ and $3^{\prime}$ primers, $2 \mu \mathrm{l}$ of reverse-transcribed cDNA, and $2.5 \mathrm{U}$ of 
AmpliTaq (Perkin-Elmer, Branchburg, NJ). Thirty cycles $\left(94^{\circ} \mathrm{C}\right.$ for 1 $\min , 52^{\circ} \mathrm{C}$ for $1 \mathrm{~min}$, and $72^{\circ} \mathrm{C}$ for $2 \mathrm{~min}$ ) were performed on a programmable thermocycler (Perkin-Elmer). The sequences of PCR primers (synthesized by Life Technologies) designed to amplify the SII region of type $\mathrm{I} \mathrm{IP}_{3}$ receptor included the upstream primer 5'GAGCTGTCTGTGCTCGTG3' and downstream primer 5'GTCGATGACCAGATTGGAG3'.

\section{Isolating outer segment proteins for Western blot}

Outer segment proteins were isolated by a protocol described previously (Panico et al., 1990). Briefly, retina was vortexed in 51\% sucrose in MOPS buffer [(in mM) 20 MOPS, $2 \mathrm{MgCl}_{2}, 100 \mathrm{KCl}, 0.1$ EDTA, 1 DTT, and 0.1 PMSF plus $0.7 \mu \mathrm{g} / \mathrm{ml}$ aprotinin, $0.7 \mu \mathrm{g} / \mathrm{ml}$ leupeptin, $0.7 \mu \mathrm{g} / \mathrm{ml}$ pepstatin A, and $0.7 \mu \mathrm{g} / \mathrm{ml}$ benzamidine], layered with more MOPS buffer, and spun for $30 \mathrm{~min}$ at $27,000 \times \mathrm{g}$. Outer segments floating at the interface were collected, diluted with MOPS buffer, and spun again. The pellet was resuspended in 38\% sucrose in MOPS buffer and passed three times through an 18 gauge needle. The preparation was layered again with MOPS buffer and spun. The orange material at the interface (now mostly outer segments) then was diluted with MOPS buffer, spun again, and saved for analysis.

\section{Western blot}

Protein samples $(5-10 \mu \mathrm{g} / \mu \mathrm{l})$ were dissolved in SDS loading buffer and separated by $8 \%$ SDS-PAGE (Laemmli, 1970). Proteins were transferred to a nitrocellulose membrane, incubated with primary antibody against type I $\mathrm{IP}_{3}$ receptor (1:500 to 1:1000 dilution) for $2 \mathrm{hr}$ at room temperature, washed, incubated $2 \mathrm{hr}$ with 1:2000 dilution of horseradish peroxidase (HRP)-conjugated goat anti-rabbit IgG (Jackson ImmunoResearch, West Grove, PA), washed, and detected by chemiluminescence (Amersham, Arlington Heights, IL).

\section{Immunohistochemistry}

Posterior eyecups from cat, monkey, rat, and rabbit were fixed with $4 \%$ paraformaldehyde and $0.01 \%$ glutaraldehyde in phosphate buffer (PB), $\mathrm{pH} 7.3$, at room temperature for $1 \mathrm{hr}$ and cryoprotected overnight in PB containing $30 \%$ sucrose.

Light microscopy. Retina was embedded in Tissue Freezing Medium (Triangle Biomedical Sciences, Durham, NC) and sectioned radially at $10 \mu \mathrm{m}$ in the cryostat. Sections were preincubated in PB containing $10 \%$ normal goat serum and $0.3 \%$ Triton X-100 for $1 \mathrm{hr}$ and then in the same solution containing primary antibody (diluted 1:200 to 1:1000) overnight at $4^{\circ} \mathrm{C}$. After being rinsed, the sections were incubated in goat anti-rabbit $\mathrm{F}\left(\mathrm{ab}^{\prime}\right)_{2}$ conjugated to a fluorescent dye for $2 \mathrm{hr}$ at room temperature, mounted in Vectashield mounting medium (Vector Laboratories, Burlingame, CA), and coverslipped.

Double labeling. For type $\mathrm{I} \mathrm{IP}_{3}$ receptor and blue-sensitive opsin (both antibodies raised in rabbit) the sections were incubated in antibody

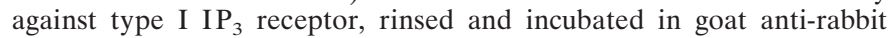
$\mathrm{F}\left(\mathrm{ab}^{\prime}\right)_{2}$ conjugated to HRP, developed with 3,3'-diaminobenzidine $(\mathrm{DAB})$ and $0.1 \%$ hydrogen peroxide, treated with glycine buffer, $\mathrm{pH} 2.2$, for 5 min to elute antibodies (DAB reaction product remains), incubated in antiserum against blue opsin, and incubated with goat anti-rabbit $\mathrm{F}\left(\mathrm{ab}^{\prime}\right)_{2}$ conjugated to $\mathrm{Cy} 3$. For type $\mathrm{I} \mathrm{IP}_{3}$ receptor and red- and greensensitive opsin (both antibodies raised in rabbit) the sections were incubated sequentially in antibody against type $\mathrm{I} \mathrm{IP}_{3}$ receptor, an excess of goat anti-rabbit Fab' fragments conjugated to FITC (to cover all rabbit epitopes), antiserum against red/green opsin, and goat anti-rabbit $\mathrm{F}\left(\mathrm{ab}^{\prime}\right)_{2}$ conjugated to rhodamine. Control experiments were similar except that the antiserum against red/green opsin was omitted. Under regular fluorescent intensity the immunoreactivity of type $\mathrm{I} \mathrm{IP}_{3}$ receptor was detected only with the FITC filter set, indicating that the second secondary antibody did not react with the first primary antibody.

Immunoelectron microscopy. Radial vibratome sections $(50-100 \mu \mathrm{m})$ were immunostained as described above except that Triton X-100 was omitted. Sections were incubated with HRP-conjugated secondary antibody, developed with DAB and hydrogen peroxide, and intensified by gold-substitution silver-intensification (Johnson and Vardi, 1998). Sections were osmicated with osmium tetroxide $(2 \% ; 1 \mathrm{hr})$, stained with uranyl acetate $(1 \%, 1 \mathrm{hr})$, dehydrated in ethanol (70-100\%), cleared in propylene oxide, and embedded in Epon 812. Ultrathin sections (70-90 $\mathrm{nm}$ ) were stained with uranyl acetate and lead citrate and viewed with a transmission electron microscope (JEOL 1200EX).

\section{Primary antibodies}

We used three different polyclonal antibodies against type $\mathrm{I} \mathrm{IP}_{3}$ receptor (all raised in rabbit). The first was raised against the $\mathrm{C}$-terminal peptide (amino acid 2731-2749; from Dr. S. K. Joseph, Thomas Jefferson University, Philadelphia, PA). The specificity of this antibody was established (Mignery et al., 1989; Joseph and Samanta, 1993; Joseph et al., 1995). The second $(\mathrm{M})$ was raised against a fusion protein containing amino acids $4466-5723$ of type $\mathrm{I} \mathrm{IP}_{3}$ receptor (Lin, 1995). The third $\left(3^{\prime} \alpha\right)$ was raised against a fusion protein containing amino acids 7761-8027 (Lin, 1995). M and $3^{\prime} \alpha$ antibodies were obtained from Dr. William Agnew, Johns Hopkins University (Baltimore, MD). We also used a monoclonal antibody to type $\mathrm{III} \mathrm{IP}_{3}$ receptor (Transduction Laboratories, Lexington, $\mathrm{KY}$ ). Rabbit polyclonal antibodies against blue and red/green opsins were obtained from Dr. Jeremy Nathans, Johns Hopkins University (Baltimore, MD).

\section{RESULTS \\ Photoreceptors express a splice variant of the type I $\mathrm{IP}_{3}$ receptor}

To determine whether the transcript of the type $\mathrm{IIP}_{3}$ receptor is expressed in photoreceptors, we performed RT-PCR. PCR primers were designed to flank the SII splicing region (Fig. 1A). In whole retina, RT-PCR amplified two major DNA products with distinct molecular sizes: 545 and 429 bp (Fig. 1B). Direct DNA sequencing from these two bands showed that the larger product contained the exons $\mathrm{A}, \mathrm{B}$, and $\mathrm{C}$ in the $\mathrm{SII}$ region $\left(\mathrm{SII}^{+}\right.$), whereas the smaller one lacked any of these exons $\left(\mathrm{SII}^{-}\right)$. In isolated photoreceptors (Fig. 1C), RT-PCR amplified only the smaller splice variant (Fig. $1 B$ ) with a DNA sequence identical to the known sequence of the splice variant lacking the $\mathrm{A}, \mathrm{B}$, and $\mathrm{C}$ exons $\left(\mathrm{SII}^{-}\right)$. This experiment was repeated three times with identical results.

To see if type $\mathrm{IIP}_{3}$ receptor is translated in photoreceptors, we prepared Western blots from whole retina (rat and cat) and from outer segments (cat) and probed them with an antibody against the $\mathrm{C}$ terminus. A prominent band at $\sim 220 \mathrm{kDa}$, corresponding to

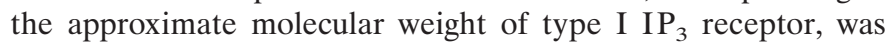
detected in all blots (Fig. 1D). Sometimes an additional band at $\sim 130 \mathrm{kDa}$ was labeled also; this is probably a degradation product (Joseph et al., 1995), but it could be a cross-reaction with a different protein. In the outer segments the major band of the expected molecular weight was prominent, and the smaller degradation product was always negligible. This suggests that the $\mathrm{SII}^{+}$splice variant of type $\mathrm{I} \mathrm{IP}_{3}$ receptor is more likely to degrade.

\section{Type I IP $\mathrm{P}_{3}$ receptor is expressed strongly in cone outer segments}

In all species tested (monkey, cat, rat, guinea pig, and rabbit),

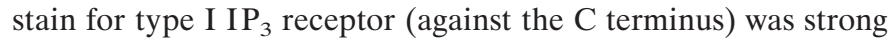
in cone outer segments but very weak in the outer plexiform layer, the inner part of the inner nuclear layer, and the ganglion cell layer (Fig. 2A). No stain was observed in the inner plexiform layer. Rod outer segments were slightly positive (especially in rat), but this was evident only in semithin and ultrathin sections (see below).

To test whether staining was specific for type $\mathrm{I} \mathrm{IP}_{3}$ receptor, we applied two additional antibodies prepared against different domains of the rat receptor. Both antibodies gave distinct staining of cone outer segments, but the background was high. Control sections incubated with the preimmune serum were negative (Fig. $2 B$, shown only for antibody "M"). A monoclonal antibody against type III $\mathrm{IP}_{3}$ receptor was negative for all retinal cells (tested in rat; data not shown). 

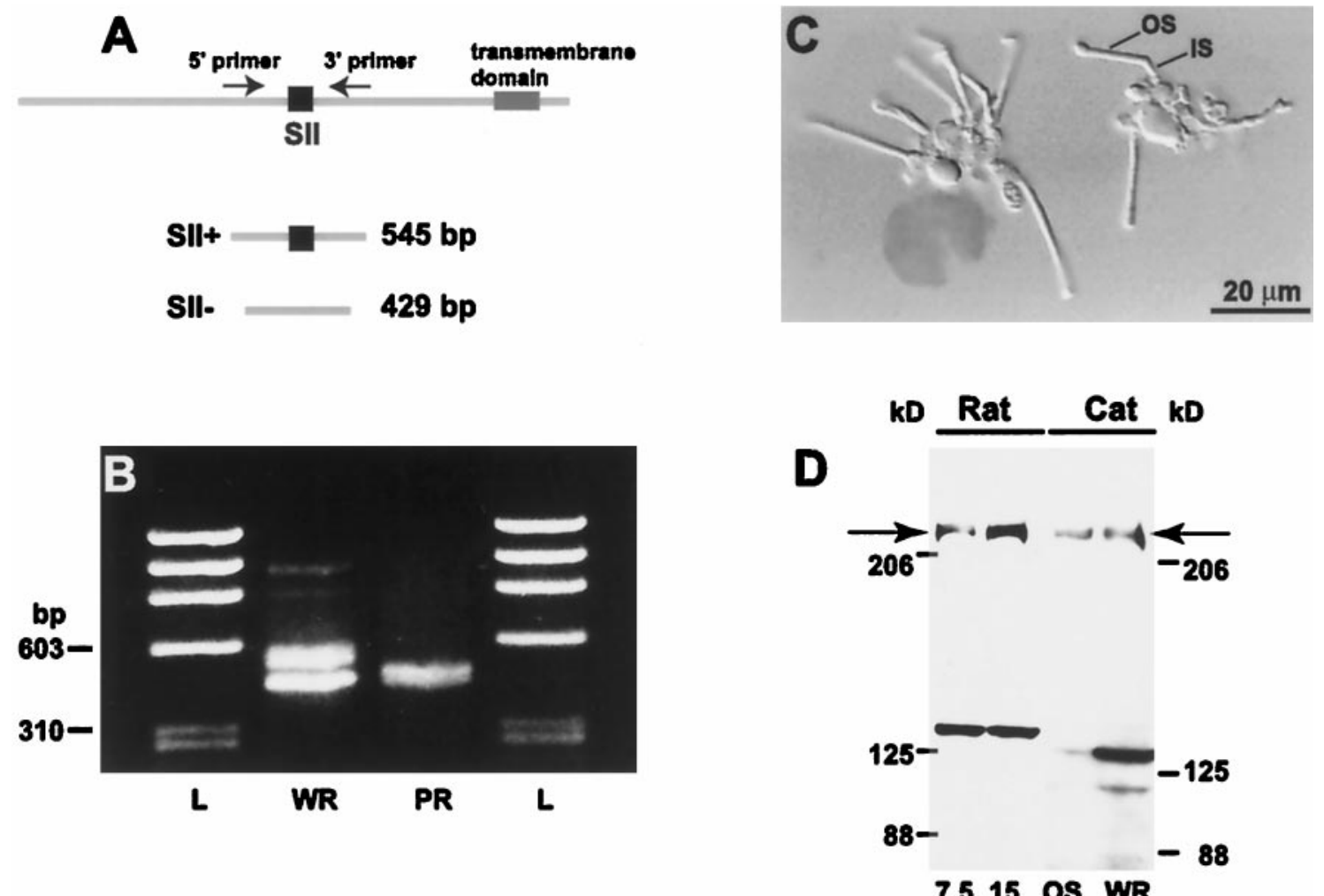

Figure 1. Mammalian retina expresses type $\mathrm{I} \mathrm{IP}_{3}$ receptor. $A$, Diagram of type $\mathrm{I} \mathrm{IP}_{3}$ receptor mRNA and location of PCR primers $($ arrows $)$. $B$, $\mathrm{RT}$-PCR of the SII-containing region of type $\mathrm{I} \mathrm{IP}_{3}$ receptor on rat whole retina $(W R)$ and isolated photoreceptors $(P R)$. $L$, DNA molecular weight ladder. $C$, Differential interference image of two groups of isolated rat photoreceptors used for RT-PCR. The outer segment $(O S)$ and inner segment (IS) are indicated. $D$, Western blots of protein extracts from rat and cat probed with C-terminus antibody against type $\mathrm{I} \mathrm{IP}_{3}$ receptor. For rat, two protein concentrations $(7.5$ and $15 \mu \mathrm{g}$ ) from whole retina were loaded. For cat, $15 \mu \mathrm{g}$ was loaded. OS, Outer segments; WR, whole retina. Arrows point to type $\mathrm{I} \mathrm{IP}_{3}$ receptor-positive band at the predicted molecular weight.

\section{Type I IP 3 receptor is not detected in $\mathbf{S}$ cones}

We noticed in monkey retina that the antibody to type $\mathrm{I}_{\mathrm{IP}_{3}}$ receptor failed to stain some cone outer segments (Fig. $3 A$, arrows). Because the blue cone comprises only $5-10 \%$ of all cones, we surmised that it was unstained. To test this, we sequentially stained sections from monkey retina for type $\mathrm{I} \mathrm{IP}_{3}$ receptor and blue-sensitive opsin. All cone outer segments negative for type $\mathrm{I} \mathrm{IP}_{3}$ receptor were strongly positive for blue-sensitive opsin (Fig. 3A,B, three experiments). We also double-labeled retina for the $\mathrm{IP}_{3}$ receptor and red- and green-sensitive opsin. All labeled cones (i.e., red and green cones) were positive for type $\mathrm{I} \mathrm{IP}_{3}$ receptor (Fig. $3 C, D$, two experiments). The blue cone in cat, rat, and rabbit (Fig. $3 E-G$ ) was also negative for type $\mathrm{I} \mathrm{IP}_{3}$ receptor.

\section{Ultrastructural localization of type $\mathbf{I ~ I P}_{3}$ receptor}

By light microscopy, stain for type $\mathrm{I} \mathrm{IP}_{3}$ receptor was strong in cone outer segments but was barely detectable in rod outer segments. To determine whether this difference merely reflected the greater thickness of the cone or whether it represented a denser expression of receptor, we examined semithin sections cut parallel to the long axis of photoreceptor outer segments. Even in these $\sim 0.5-\mu \mathrm{m}$-thick sections, one-half the thickness of a rod outer segment, cones stained much more strongly than rods (Fig. $4 A$ ). Furthermore, at the electron microscope level, gold particles representing immunostaining were denser in cone outer segments than in rods (Fig. $5 A, B$ ). Stronger cone staining might occur if the disks communicate with the extracellular space, as they do in amphibians (Laties and Liebman, 1970), for this might render them more accessible to the antibody. However, disks in mammalian cones commonly are closed, as in rod (Cohen, 1970; Anderson and Fisher, 1976; Rodieck, 1988). Therefore, in cone and rod, access of antibody to the $\mathrm{IP}_{3}$ receptor may be similar. When equal access was assured by treating the tissue with a high concentration of detergent $(0.5 \%)$, cone staining compared with rods was even more pronounced. Therefore, greater cone staining probably reflects their stronger expression of type $\mathrm{IIP}_{3}$ receptor.

Most immunostain was localized to the cytoplasmic face of the disk and plasma membrane (Fig. 6A). This was easiest to see where disks were swollen, because the disk lumen then could be distinguished clearly from the cytoplasmic space (Fig. 6B). Staining of the cytoplasmic face matches the topology of the receptor, because its $\mathrm{C}$ terminus (target of the antibody) is thought to be cytoplasmic (Mikoshiba et al., 1994). In rods the sparse staining might be nonspecific; however, because the gold particles were located only on the cytoplasmic face of the membrane, they probably represent genuine, although weak, expression of $\mathrm{IP}_{3}$ receptor.

Thin sections also revealed stain over the rod cilium that connects the inner and outer segment (see Fig. 4A). Within the cilium, stain was concentrated along the microtubules (see Fig. $4 B$ ). Staining also was observed in the cone cilium (see Fig. $4 A$ ), but microtubules were not discerned easily.

\section{DISCUSSION}

We provide strong evidence that the type $\mathrm{I}_{\mathrm{IP}_{3}}$ receptor is expressed in photoreceptor outer segments, especially in red- and 


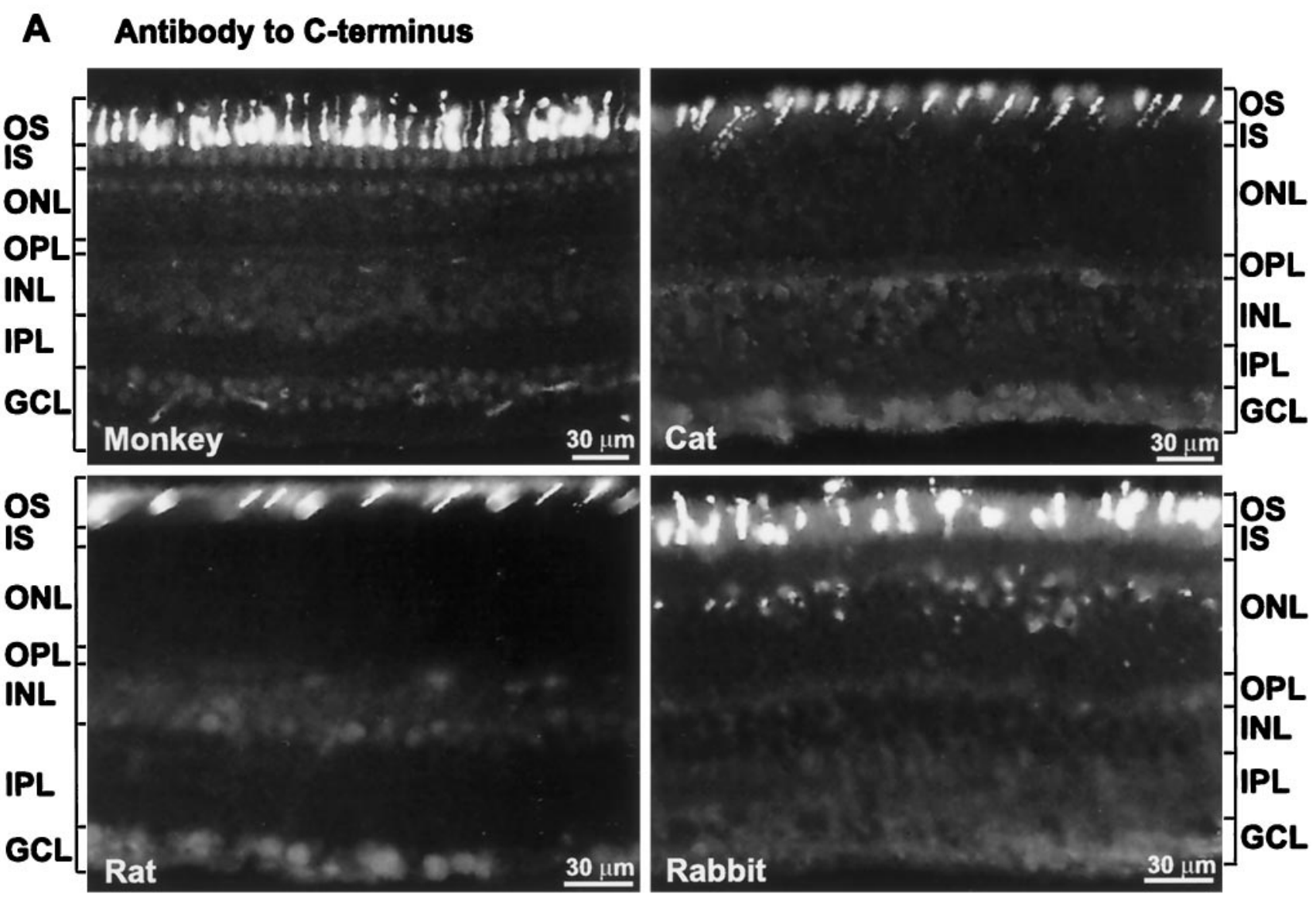

\section{B Antibody to internal domain}

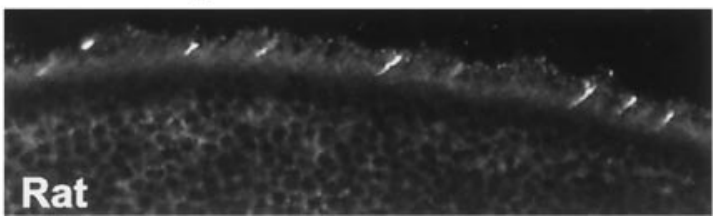

Pre-immune serum

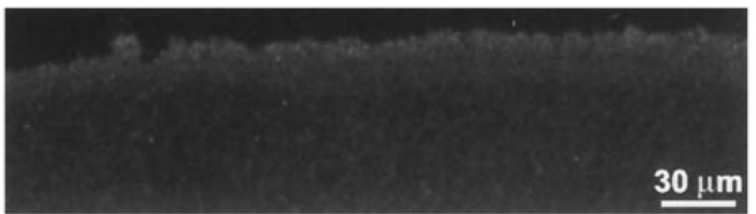

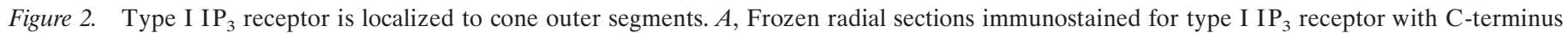

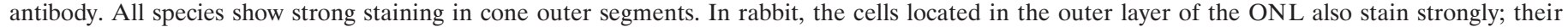

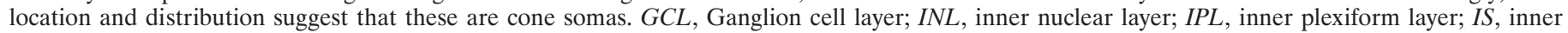

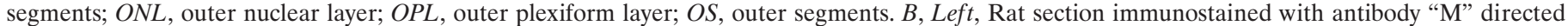

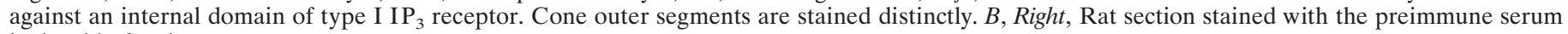
is devoid of stain.

green-sensitive cones: (1) mRNA of a particular splice variant (SII ${ }^{-}$) was amplified from isolated photoreceptors; (2) a single protein band with the expected molecular weight was demonstrated by Western blot of the outer segments; (3) strong staining for the receptor was detected with three different antibodies, whereas controls (preimmune serum) were negative; (4) antibody against the $\mathrm{C}$ terminus was localized to the cytoplasmic face of the disk and the plasma membrane, in accordance with the known receptor topology (Mikoshiba et al., 1994).

The finding of $\mathrm{IP}_{3}$ receptor on the outer face of the disk supports previous findings that $\mathrm{IP}_{3}$ can release $\mathrm{Ca}^{2+}$ from internal stores (Parker et al., 1986; Schnetkamp and Szerencsei, 1993; Schnetkamp, 1995b). Because $\mathrm{IP}_{3}$ usually is associated with smooth endoplasmic reticulum, localization of the type $\mathrm{I}_{3}$ receptor on the plasma membrane may seem surprising. However, $\mathrm{IP}_{3}$ receptor also localizes to plasma membrane in olfactory cilia, mast cells, and T-lymphocytes (Kuno and Gardner, 1987; Penner et al., 1988; Cunningham et al., 1993). This site can admit $\mathrm{Ca}^{2+}$ from the extracellular space, where the concentration $(\sim 3$ $\mathrm{mm}$ ) is apparently the same as in the disk lumen (for review, see Schnetkamp, 1989). In mammals, because disk surface area is greater than plasma membrane surface area, the disks probably provide most of the $\mathrm{IP}_{3}$-mediated $\mathrm{Ca}^{2+}$ influx.

\section{Possible function of type $I \mathrm{IP}_{3}$ receptor in red- and} green-sensitive cones

$\mathrm{Ca}^{2+}$ plays a key role in terminating the light response and adaptation (Fig. 7). When light via the rhodopsin cascade reduces 
Monkey
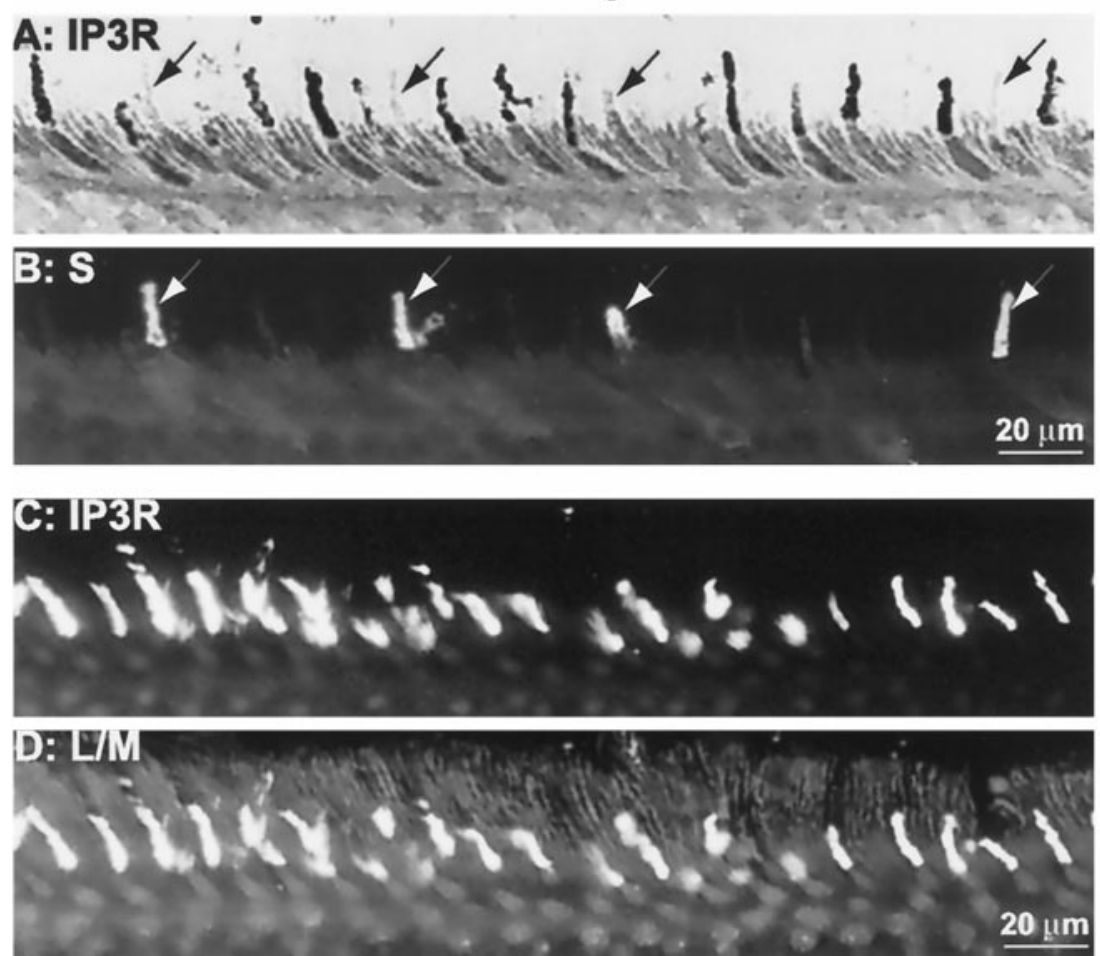

Cat
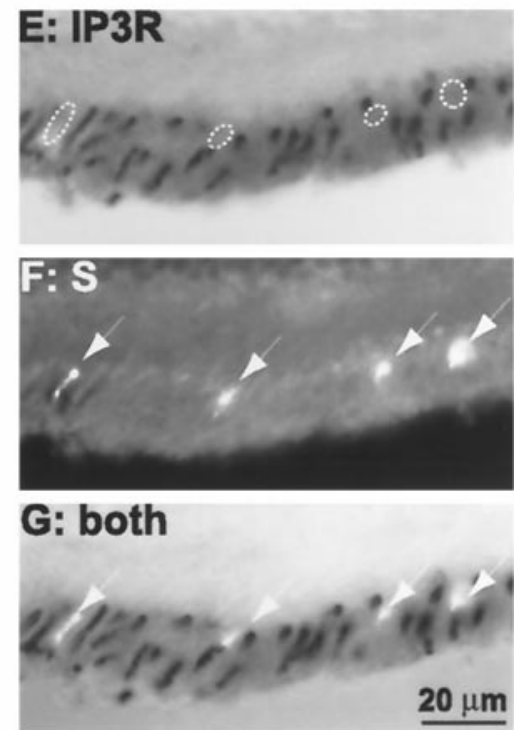

Figure 3. $\mathrm{S}$ cones do not stain for type $\mathrm{I} \mathrm{IP}_{3}$ receptor. $A, B$, Monkey retina stained with antibodies against type $\mathrm{I}_{\mathrm{IP}}$ receptor $(A$; visualized with $\mathrm{DAB}$ reaction product) and blue-sensitive opsin $(B$; visualized with $\mathrm{Cy} 3)$. Arrows point to $\mathrm{S}$ cone outer segments that are negative for type I I $\mathrm{P}_{3}$ receptor but are positive for blue-sensitive opsin. $C, D$, Monkey retina stained with antibodies against type I IP ${ }_{3}$ receptor $(C$; FITC) and red/green opsin $\left(D\right.$; rhodamine). All cone outer segments stained for type $\mathrm{I} \mathrm{IP}_{3}$ receptor are also positive for red- and green-sensitive opsin. $E-G, \mathrm{Cat}$ retina stained with antibodies against type $\mathrm{I} \mathrm{IP}_{3}$ receptor $(E ; \mathrm{DAB})$ and blue-sensitive opsin $(F ; \mathrm{Cy} 3)$. Dotted outlines in $E$ designate the location of the blue cone outer segments. $G$, Simultaneous visualization of both stainings: cone outer segments stained for the blue opsin do not stain for type $\mathrm{I} \mathrm{IP}_{3}$ receptor.

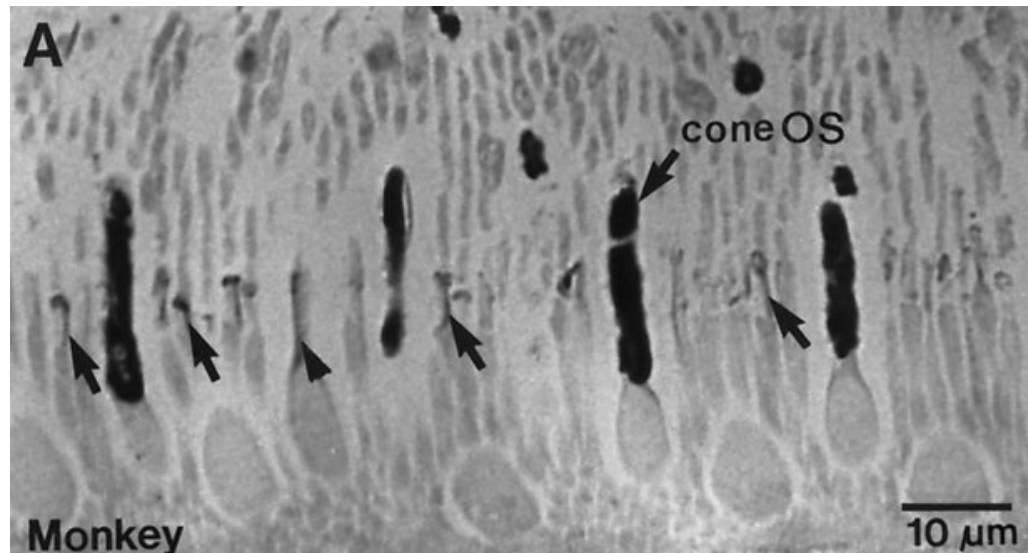

Figure 4. Stain for type $\mathrm{I} \mathrm{IP}_{3}$ receptor in cones is stronger than in rods, and it is also present in connecting cilia (monkey). $A$, Light micrograph of a $1 \mu \mathrm{m}$ Epon section; cone outer segments (cone $O S$ ) are much stronger than rod outer segments. Arrows indicate stained connecting cilia in rods; the arrowhead indicates stained connecting cilium in a cone. $B$, Electron micrograph of a rod connecting cilium $(c)$. Arrows indicate the staining (gold deposits) along the tubular structures of the connecting cilium. $I S$, Inner segment; $O S$, outer segment.

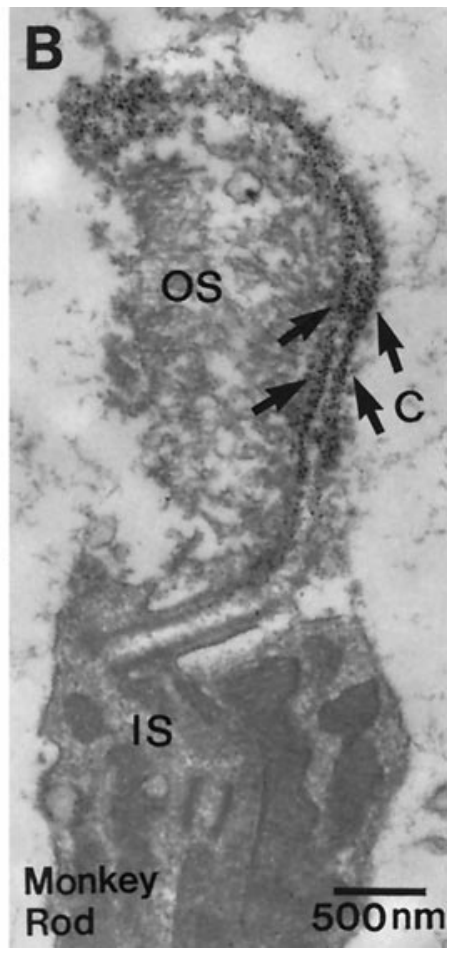




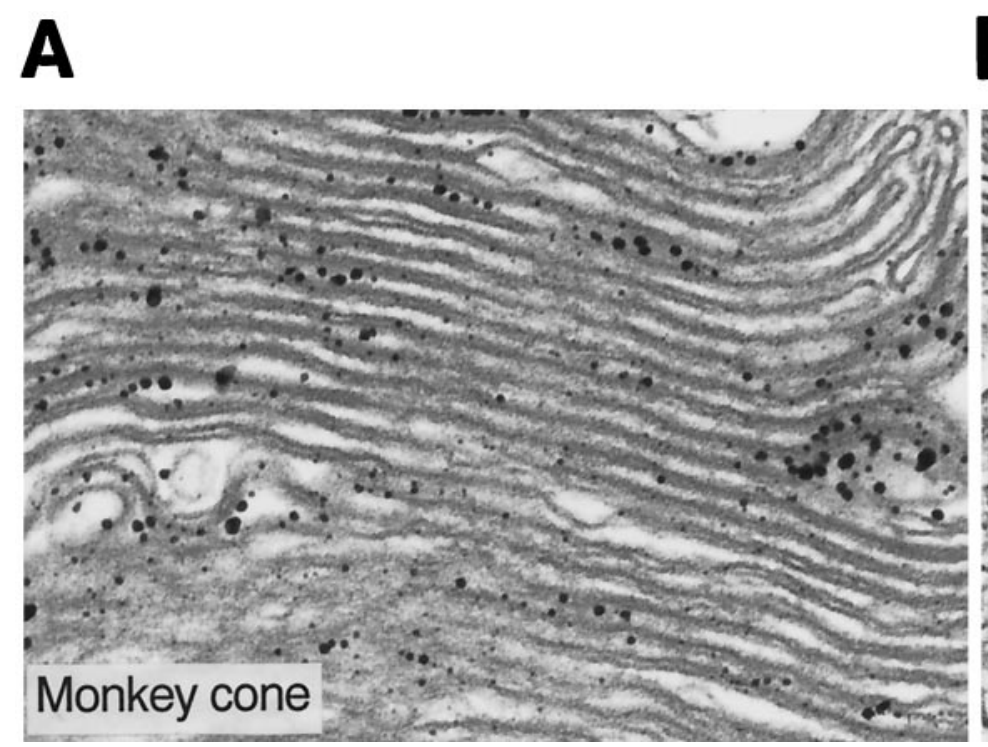

\section{B}

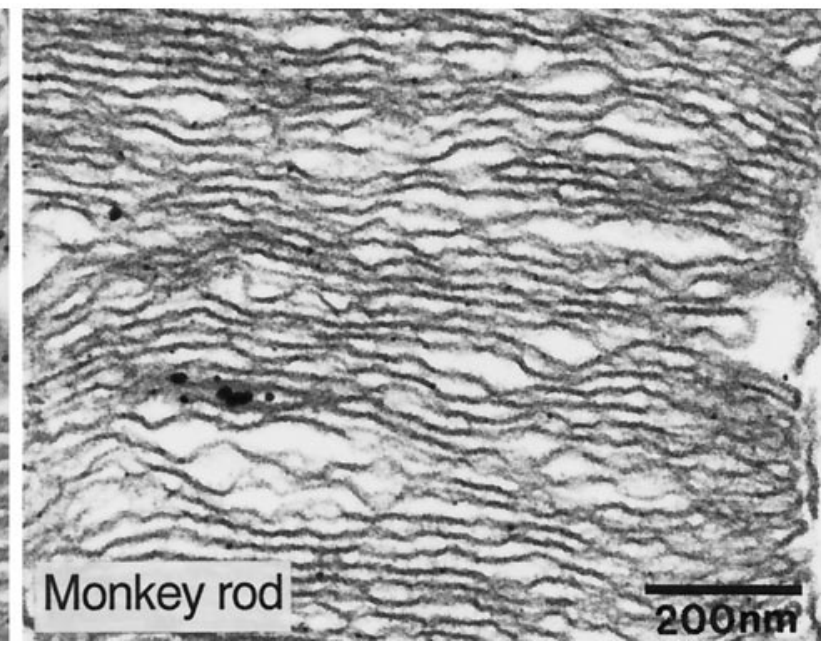

Figure 5. Type $\mathrm{I} \mathrm{IP}_{3}$ receptor is localized to cone and rod disk membranes (monkey). $A$, In the cone outer segment the immunodeposits are dense. In a fixed tissue the hypertonic condition often causes the disk membrane to collapse, which leads to a narrow intradisk lumen and wide interdisk space (or cytoplasmic space). Almost all of the immunodeposits are in the cytoplasmic space. $B$, In the rod outer segments the immunodeposits are scattered.

\section{A}

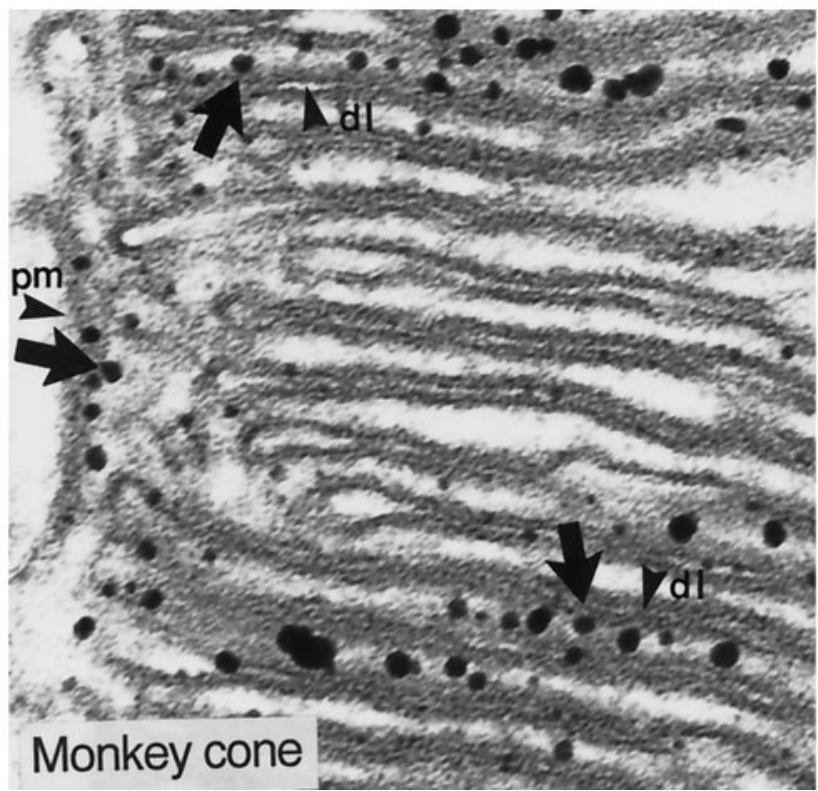

B

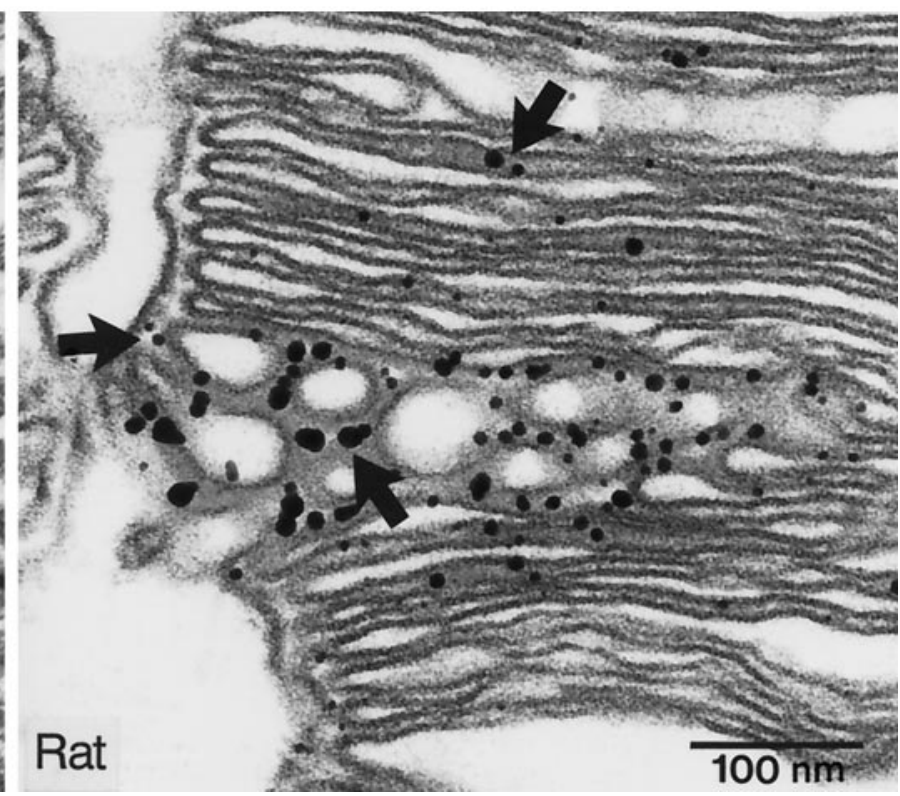

Figure 6. Staining for type $\mathrm{I} \mathrm{IP}_{3}$ receptor is present on the cytoplasmic face of the plasma membrane. A, Monkey cone outer segment. Arrowheads indicate disk lumen $(d l)$ and plasma membrane $(\mathrm{pm})$. Arrows indicate that the staining is associated at the cytoplasmic side of disk and plasma membranes. $B$, In rat it is difficult to discriminate cones from rods, but because rods are 100 -fold more abundant and most neighboring outer segments appear similar to this one, we think that it is a rod outer segment. Arrows indicate that the staining is associated at the cytoplasmic side of disk membranes.

cGMP, $\mathrm{Ca}^{2+}$ influx through the cGMP-gated channel decreases and, as extrusion continues, cytoplasmic $\mathrm{Ca}^{2+}$ declines. Lower $\mathrm{Ca}^{2+}$ (1) activates rhodopsin kinase, (2) inhibits phosphodiesterase, (3) activates guanylyl cyclase, and (4) increases the affinity of the cGMP-gated channel for its ligand. All of these effects help to terminate the light response and adapt the photoreceptor (i.e., reduce gain and restore sensitivity to a stronger light). A quantitative model of the rod response does not require an additional mechanism to modulate $\mathrm{Ca}^{2+}$ (Lamb and Pugh, 1992; Lyubarsky and Pugh, 1996; Nikonov et al., 1998). However, the cone recovers faster than the rod and is less sensitive. Conceivably, the abundant $\mathrm{IP}_{3}$ receptor on cone disk membranes might contribute to these response properties as we now explain.

The $\mathrm{IP}_{3}$ receptor might provide a positive feedback loop (Fig. 7). This would accelerate the fall of cytoplasmic $\mathrm{Ca}^{2+}$ after a light flash or its rise after a dark flash. Phospholipase C (PLC), 


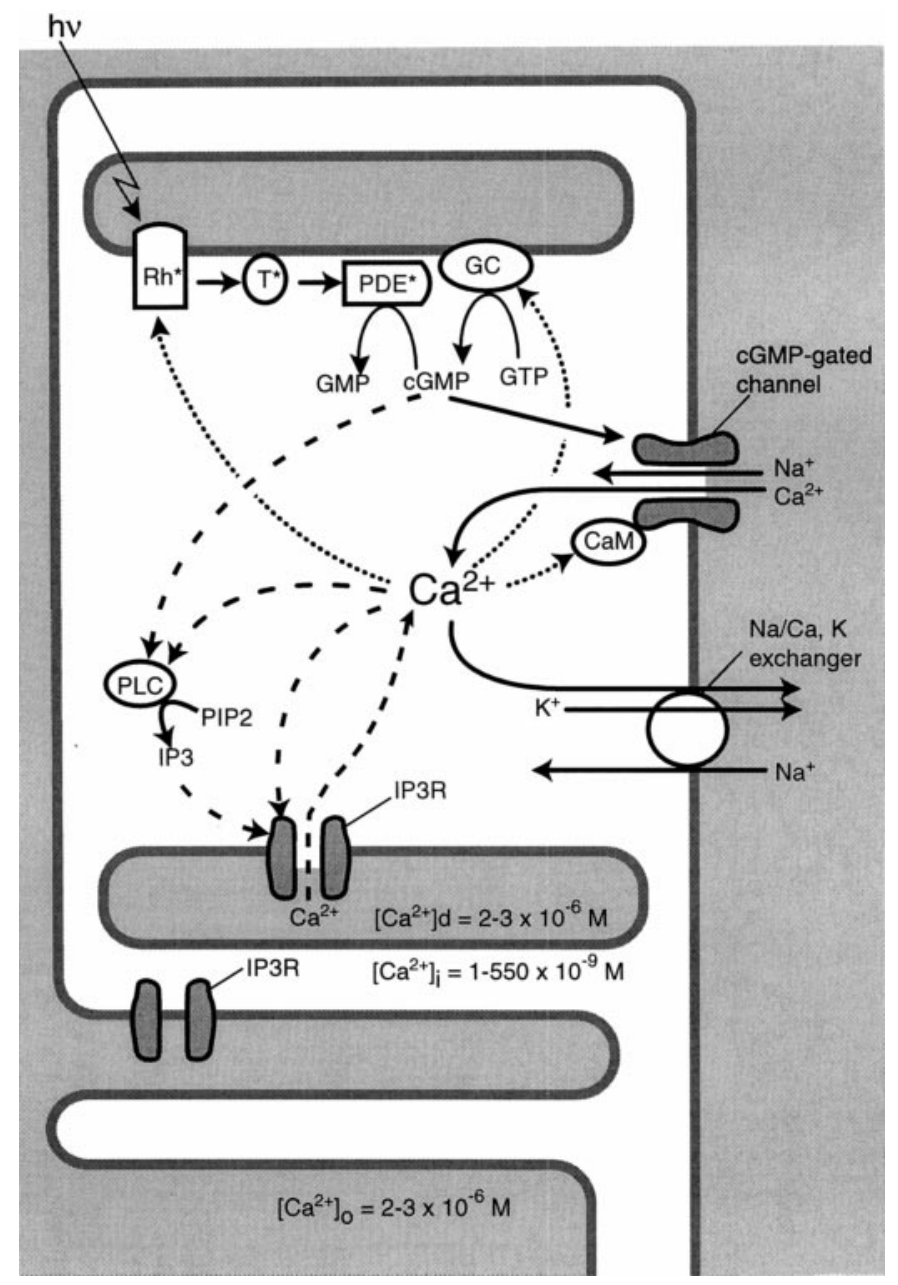

Figure 7. How the $\mathrm{IP}_{3}$ receptor might contribute to response recovery and adaptation. Solid arrows mark the phototransduction cascade leading from light $(h v)$ to the successive activation of opsin $\left(R h^{*}\right)$, transducin $\left(T^{*}\right)$, phosphodiesterase $\left(P D E^{*}\right)$, and the hydrolysis of cGMP. Cation channels gated by cGMP close, thereby reducing $\mathrm{Ca}^{2+}$ influx, but $\mathrm{Ca}^{2+}$ extrusion continues, so cytoplasmic $\mathrm{Ca}^{2+}$ falls. Low cytoplasmic $\mathrm{Ca}^{2+}$ affects several processes that terminate the light response and contribute to the response recovery (dotted arrows): opsin is phosphorylated, guanylyl cyclase $(G C)$ is activated to synthesize cGMP, and channel affinity for cGMP is increased by binding $\mathrm{Ca}^{2+} /$ calmodulin $(\mathrm{CaM})$. The $\mathrm{IP}_{3}$ receptor $(I P 3 R)$ on the disk and plasma membranes would accelerate changes in $\mathrm{Ca}^{2+}{ }_{\mathrm{i}}$ (dashed arrows). When $\mathrm{Ca}^{2+}$ and cGMP fall, phospholipase $\mathrm{C}$ $(P L C)$ is suppressed, reducing $\mathrm{IP}_{3}$. Because both $\mathrm{IP}_{3}$ and $\mathrm{Ca}^{2+}$ regulate the $\mathrm{IP}_{3}$ receptor, their fall reduces $\mathrm{Ca}^{2+}$ mobilization from the disks and extracellular space. This positive feedback loop via the $\mathrm{IP}_{3}$ receptor should accelerate the fall of $\mathrm{Ca}^{2+}$ after a light stimulus and its rise after a dark stimulus.

the enzyme that produces $\mathrm{IP}_{3}$, is present in cones [Ferreira and Pak (1994), but see Peng et al. (1997) and discussion below] where it might be stimulated constitutively by cGMP and $\mathrm{Ca}^{2+}$ (Ghalayini and Anderson, 1987; Rhee and Bae, 1997; Haque et al., 1998). Therefore, light ONset, by reducing cGMP and $\mathrm{Ca}^{2+}$, would inhibit PLC. This would reduce $\mathrm{IP}_{3}$ and thus the release of intradisk $\mathrm{Ca}^{2+}$. The $\mathrm{IP}_{3}$ ligand binding of the receptor is increased by $\mathrm{Ca}^{2+}$ up to $\sim 200 \mathrm{~nm}$ but is reduced above this level (Bezprozvanny et al., 1991; Li et al., 1995; Patel and Taylor, 1995; López-Colomè and Lee, 1996; Kaznacheyeva et al., 1998). In darkness, cytoplasmic $\mathrm{Ca}^{2+}$ is near this optimum for $\mathrm{IP}_{3}$ binding (Korenbrot, 1995), so the fall in $\mathrm{Ca}^{2+}$ after light stimulation would reduce $\mathrm{IP}_{3}$ binding and accelerate the fall in $\mathrm{Ca}^{2+}$. At light OFFset, $\mathrm{Ca}^{2+}$ influx via the cGMP-gated channel rises. This would activate $\mathrm{IP}_{3}$ binding and accelerate the rise of cytoplasmic $\mathrm{Ca}^{2+}$. This loop for accelerating the rise of $\mathrm{Ca}^{2+}$ would cease as $\mathrm{Ca}^{2+}$ rises beyond the optimal concentration for $\mathrm{IP}_{3}$ binding.

Two points might seem inconsistent with the model. First, although biochemistry suggests an $\mathrm{IP}_{3}$ signaling system in purified photoreceptor outer segments, physiology finds no such effect on the light response of intact cells. However, most physiology has focused on rods in which the pathway is minor. Second, although light on isolated disk membranes increases $\mathrm{IP}_{3}$, our model shows light decreasing $\mathrm{IP}_{3}$. However, both $\mathrm{PLC}$ and the $\mathrm{IP}_{3}$ receptor depend critically on the $\mathrm{Ca}^{2+}$ level, so the decisive test requires an intact cell.

It remains unclear which isoform of PLC is expressed by cones. Ferreira and Pak (1994) identified PLC- $\beta 4$, but Peng et al. (1997) did not concur. The issue matters because PLC- $\beta$ is activated by a member of the $G_{\mathrm{q}}$ family, whereas other PLC isoforms are activated differently, for example, by a different $G$-protein $\left(G_{h}\right)$, a tyrosine kinase, or a lipid-derived second messenger (for review, see Rhee and Bae, 1997).

If the $\mathrm{IP}_{3}$ receptor accelerates the cone response, why is it absent from the blue-sensitive cone? Possibly the blue-sensitive cone expresses a different isoform; alternatively, the bluesensitive cone and the rod both express the $\mathrm{IP}_{3}$ receptor at very low levels. Vision mediated by the blue cone does share several features with rod vision. For example, both have a longer integration time and a higher sensitivity than vision mediated by redand green-sensitive cones (Brindley et al., 1966; Mollon and Polden, 1977a,b; Zrenner and Gouras, 1979, 1981; Williams et al., 1981; Nelson, 1985). Conceivably, the extra loop for rapidly driving cytoplasmic $\mathrm{Ca}^{2+}$ through larger excursions is reduced or absent because it would ill serve a slower, more sensitive response.

\section{REFERENCES}

Anderson DH, Fisher SK (1976) The photoreceptors of diurnal squirrels: outer segment structure disc shedding and protein renewal. J Ultrastruct Res 55:119-141.

Berridge MJ (1993) Inositol triphosphate and calcium signaling. Nature 361:315-325.

Bezprozvanny I, Watras J, Ehrlich BE (1991) Bell-shaped calcium-response curves in Ins $1,4,5-\mathrm{P}_{3}$ - and calcium-gated channels from endoplasmic reticulum of cerebellum. Nature 351:751-754.

Brindley GS, Croz JJD, Rushton WAH (1966) The flicker fusion frequency of the blue-sensitive mechanism of colour vision. J Physiol (Lond) 183:497-500.

Brown JE, Blazynski C, Cohen AI (1987) Light induces a rapid and transient increase in inositol triphosphate in toad rod outer segments. Biochem Biophys Res Commun 146:1392-1396.

Chomzynski P, Sacchi N (1987) Single-step method of RNA isolation by acid guanidium thiocyanate-phenol-chloroform extraction. Anal Biochem 162:156-159.

Cohen AI (1970) Further studies on the question of the patency of saccules in outer segments of vertebrate photoreceptors. Vision Res 10:445-453.

Cunningham AM, Ryugo DK, Sharp AH, Reed RR, Snyder SH, Ronnett GV (1993) Neuronal inositol 1,4,5-triphosphate receptor localized to the plasma membrane of olfactory cilia. Neuroscience 57:339-352.

Danoff SK, Ferris CD, Donath C, Fischer GA, Munemitsu S, Ullrich A, Snyder SH, Ross CA (1991) Inositol 1,4,5-triphosphate receptors: distinct neuronal and nonneuronal forms derived by alternative splicing differ in phosphorylation. Proc Natl Acad Sci USA 88:2951-2955.

Day NS, Koutz CA, Anderson RE (1993) Inositol 1,4,5-triphosphate receptors in the vertebrate retina. Curr Eye Res 12:981-992.

Fain GL, Schroder WH (1985) Calcium content and calcium exchange in dark-adapted toad rods. J Physiol (Lond) 368:641-665. 
Ferreira PA, Pak WL (1994) Bovine phospholipase C highly homologous to the NorpA protein of Drosophila is expressed specifically in cones. J Biol Chem 269:3129-3131.

Ghalayini A, Anderson RE (1984) Phosphatidylinositol 4,5-biphosphate: light-mediated breakdown in the vertebrate retina. Biochem Biophys Res Commun 124:503-506.

Ghalayini AJ, Anderson RE (1987) Activation of bovine rod outer segment phospholipase C by ATP and GTP. Neurosci Res Commun 1:119-127.

Haque R, Uchida K, Iuvone PM (1998) 8-Br-cGMP and cGMP phosphodiesterase (PDE) inhibitors stimulate intracellular calcium levels and inositol phosphate accumulation in cultured chick photoreceptor cells. Invest Ophthalmol Vis Sci 39:S1056.

Hayashi F, Amakawa T (1985) Light-mediated breakdown of phosphatidylinositol 4,5-bisphosphate in isolated rod outer segments of frog photoreceptor. Biochem Biophys Res Commun 128:954-959.

Johnson MA, Vardi N (1998) Regional differences in GABA and GAD immunoreactivity in rabbit horizontal cells. Vis Neurosci 15:743-753.

Joseph SK, Samanta S (1993) Detergent solubility of the inositol triphosphate receptor in rat brain membranes. Evidence for association of the receptor with ankyrin. J Biol Chem 268:6477-6586.

Joseph SK, Lin C, Pierson S, Thomas AP, Maranto AR (1995) Heterooligomers of type-I and type-III inositol triphosphate receptors in WB rat liver epithelial cells. J Biol Chem 270:23310-23316.

Kaznacheyeva E, Lupu VD, Bezprozvanny I (1998) Single-channel properties of inositol 1,4,5-triphosphate receptor heterologously expressed in HEK-293 cells. J Gen Physiol 111:847-856.

Koch K-W (1995) Control of photoreceptor proteins by $\mathrm{Ca}^{2+}$. Cell Calcium 18:314-321.

Korenbrot JI (1995) $\mathrm{Ca}^{2+}$ flux in retinal rod and cone outer segments: differences in $\mathrm{Ca}^{2+}$ selectivity of the cGMP-gated ion channels and $\mathrm{Ca}^{2+}$ clearance rates. Cell Calcium 18:285-300.

Koutalos Y, Yau K-W (1996) Regulation of sensitivity in vertebrate rod photoreceptors by calcium. Trends Neurosci 19:73-81.

Kuno M, Gardner P (1987) Ion channels activated by inositol 1,4,5triphosphate in plasma membrane of human T-lymphocytes. Nature 326:19-25.

Laemmli EK (1970) Cleavage of structural proteins during the assembly of the head of bacteriophage T4. Nature 227:680-685.

Lamb TD, Pugh Jr EN (1992) G-protein cascades: gain and kinetics. Trends Neurosci 15:291-298.

Lamb TD, Torre V (1990) The control of photoreceptor sensitivity. In: Progress in cell research (Ritchie JM, Magistretti PJ, Bolis L, eds), pp 109-120. Amsterdam: Elsevier Science.

Laties AM, Liebman PA (1970) Cones of living amphibian eye: selective staining. Science 168:1475-1476.

Li YX, Keizer J, Stojilkovic SS, Rinzel J (1995) $\mathrm{Ca}^{2+}$ excitability of the ER membrane: an explanation for $\mathrm{IP}_{3}$-induced $\mathrm{Ca}^{2+}$ oscillations. Am $\mathrm{J}$ Physiol 269:C1079-C1092.

Liebman PA (1974) Light-dependent $\mathrm{Ca}^{2+}$ content of rod outer segment disc membranes. Invest Ophthalmol 13:700-701.

Lin DDM (1995) Expression and characterization of two alternatively spliced isoforms of rat type I receptor for inositol 1,4,5-triphosphate. $\mathrm{PhD}$ thesis, The Johns Hopkins School of Medicine.

López-Colomé AM, Lee I (1996) Pharmacological characterization of inositol 1,4,5-triphosphate binding to membranes from retina and retinal cultures. J Neurosci Res 44:149-156.

Lyubarsky AL, Pugh Jr EN (1996) Recovery phase of the murine rod photoresponse reconstructed from electroretinographic recordings. J Neurosci 16:563-571.

McNaughton PA (1995) Rods, cones, and calcium. Cell Calcium 18:275-284.

Mignery GA, Südhof TC, Takei K, de Camilli P (1989) Putative receptor for inositol 1,4,5-triphosphate similar to ryanodine receptor. Nature 342:192-194.
Mikoshiba K, Furuichi T, Miyawaki A (1994) Structure and function of $\mathrm{IP}_{3}$ receptors. Cell Biol 5:273-281.

Mollon JD, Polden PG (1977a) An anomaly in the response of the eye to light of short wavelengths. Philos Trans R Soc Lond [Biol] 278:207-240.

Mollon JD, Polden PG (1977b) Saturation of a retinal cone mechanism. Nature 265:243-246.

Nakagawa T, Okano H, Furuichi T, Aruga J, Mikoshiba K (1991) The subtypes of the mouse inositol 1,4,5-triphosphate receptor are expressed in a tissue-specific and developmentally specific manner. Proc Natl Acad Sci USA 88:6244-6248.

Nelson R (1985) Spectral properties of cat horizontal cells. Neurosci Res Suppl 2:S167-S183.

Nicol GD, Kaupp UB, Bownds MD (1987) Transduction persists in rod photoreceptors after depletion of intracellular calcium. J Gen Physiol 89:297-319.

Nikonov S, Engheta N, Pugh Jr EN (1998) Kinetics of recovery of the dark-adapted salamander rod photoresponse. J Gen Physiol 111:7-37.

Nucifora FC, Li S-H, Danoff S, Ullrich A, Ross CA (1995) Molecular cloning of a cDNA for the human inositol 1,4,5-triphosphate receptor type I, and the identification of a third alternatively spliced variant. Mol Brain Res 32:291-296.

Panico J, Parkes JH, Liebman PA (1990) The effect of GDP on rod outer segment G-protein interactions. J Biol Chem 265:18922-18927.

Parker KR, Briggs JA, Dratz EA (1986) Inositol triphosphate stimulates $\mathrm{Ca}^{2+}$ release form toad retinal rod outer segment preparations. Vis Recept 49:31A.

Patel S, Taylor CW (1995) Quantal responses to inositol 1,4,5triphosphate are not a consequence of $\mathrm{Ca}^{2+}$ regulation of inositol 1,4,5-triphosphate receptors. Biochem J 312:789-794.

Peng Y-W, Sharp AH, Snyder SH, Yau K-W (1991) Localization of the inositol 1,4,5-triphosphate receptor in synaptic terminals on the vertebrate retina. Neuron 6:525-531.

Peng Y-W, Rhee SG, Yu W-P, Ho Y-K, Schoen T, Chader GJ, Yau K-W (1997) Identification of components of a phosphoinositide signaling pathway in retinal rod outer segments. Proc Natl Acad Sci USA 94:1995-2000.

Penner R, Matthews G, Neher E (1988) Regulation of calcium influx by second messengers in rat mast cells. Nature 334:499-504.

Rhee SG, Bae YS (1997) Regulation of phosphoinositide-specific phospholipase C isozymes. J Biol Chem 272:15045-15048.

Rodieck RW (1988) The primate retina. In: Comparative primate biology, Vol 4, Neurosciences, pp 203-278. New York: Liss.

Sasaki T, Kaneko A (1996) L-Glutamate-induced responses in OFF-type bipolar cells of the cat retina. Vision Res 36:787-795.

Schnetkamp PPM (1989) Na-Ca or Na-Ca-K exchange in rod photoreceptors. Prog Biophys Mol Biol 54:1-29.

Schnetkamp PPM (1995a) How does the retinal rod Na-Ca+-K exchanger regulate cytosolic free $\mathrm{Ca}^{2+}$ ? J Biol Chem 270:13231-13239.

Schnetkamp PPM (1995b) Calcium homeostasis in vertebrate retinal rod outer segments. Cell Calcium 18:322-330.

Schnetkamp PP, Bownds MD (1987) $\mathrm{Na}^{+}$- and cGMP-induced $\mathrm{Ca}^{2+}$ fluxes in frog rod photoreceptors. J Gen Physiol 89:481-500.

Schnetkamp PPM, Szerencsei RT (1993) Intracellular $\mathrm{Ca}^{2+}$ sequestration and release in intact bovine retinal rod outer segments. J Biol Chem 268:12449-12457.

Williams DR, MacLeod DIA, Hayhoe MM (1981) Punctate sensitivity of the blue-sensitive mechanism. Vision Res 21:1357-1375.

Yau K-W (1994) Phototransduction mechanism in retinal rods and cones. Invest Ophthalmol Vis Sci 35:9-32.

Zrenner E, Gouras P (1979) Blue-sensitive cones of the cat produce a rod-like electroretinogram. Invest Ophthalmol Vis Sci 18:1076-1081.

Zrenner E, Gouras P (1981) Characteristics of the blue-sensitive cone mechanism in primate retinal ganglion cells. Vision Res 21:1605-1609. 